\section{Analisis Efektivitas dan Laju Pertumbuhan Pajak Daerah serta Kontribusinya Terhadap Pendapatan Asli Daerah Kota Bogor Periode 2013-2017}

\author{
Secillia Herjanti dan I Wayan Teg Teg \\ Program Studi Akuntansi, Institut Bisnis dan Informatika Kesatuan \\ Bogor, Indonesia \\ E-Mail: secilliaherjanti@gmail.com
}

Taxes and Local

Revenue

Submitted: FEBRUARI 2020

Accepted: APRIL 2020

\begin{abstract}
With the existence of regional autonomy in force in Indonesia, autonomous regions, both provinces and districts/cities must be able to their own regions and are required to increase Local Revenue (PAD) in order to be able to finance government administration and improve services to the community. Local revenue aims to give authority to the Regional Government to fund the implementation of regional autonomy in accordance with regional potential as the realization of decentralization. Bogor City is one of the regions that implements the regional autonomy policy. The biggest source of the local revenue in Bogor comes from local taxes. The importance of tax as a source of development funding has been determined in various government legislative products. Taxes for local governments serve as the main source of income and also as a regulator. So in the development of a region, taxes play an important role in a development, including hotel tax, restaurant tax and entertainment tax. Bogor has the potential to develop local taxes from the tourism sector to be able to increase its local revenue. The purpose of this study was to determine the level of effectiveness of hotel tax collection, restaurant tax and entertainment tax in Bogor period 2013-2017, knowing how much the growth rate of hotel tax, restaurant tax and entertainment tax in Bogor City period 2013-2017 and how much the tax contribution hotel, restaurant tax and entertainment tax on Local Revenue in Bogor period 2013-2017. The method used in this study is a qualitative descriptive method. The results of this study that the effectiveness of hotel tax, restaurant tax and entertainment tax for the period 2013-2017 in Bogor has included a very effective criterion with the effectiveness of collecting hotel taxes, restaurant taxes and entertainment that exceeds $100 \%$ each year. The average growth rate of hotel tax, restaurant tax and entertainment tax for the period 2013-2017 in Bogor are as follows, 14.15\%, 17.55\% and 11.93\%. There is an increase / decrease in the growth rate of hotel taxes, restaurant tax and entertainment tax every year due to several factors including the existence of central government policies, the influence of the increase I decline in the number of visitors who come, and the level of tourists visiting Bogor City. Meanwhile, the average contribution of hotel tax, restaurant tax and entertainment tax on PAD for the 2013-2017 period in the Bogor amounted to $8.58 \%$ with very less criteria, $11.50 \%$ with less criteria and $3.09 \%$ with very less criteria. The decrease in the contribution of hotel tax, restaurant tax and entertainment tax is influenced by the existence of central government policies, the number of visitors and the increase in the number of realization of other local tax revenues which is quite significant.
\end{abstract}

Keywords: local revenue, hotel tax, restaurant tax, entertainment tax

\title{
PENDAHULUAN
}

JIAKES

Sebagai konsekuensi menjalankan otonomi daerah, maka masing-masing daerah dituntut untuk berupaya meningkatkan sumber Pendapatan Asli Daerah (PAD) agar mampu membiayai penyelenggaraan pemerintah dan lebih meningkatkan pelayanan kepada masyarakat. PAD bertujuan memberikan kewenangan kepada Pemerintah

Jurnal Ilmiah Akuntansi Kesatuan Vol. 8 No. 1, 2020 pg. $37-48$
IBI Kesatuan IBI Kesatuan
ISSN 2337-7852 E-ISSN $2721-3048$ 
Taxes and Local

Revenue

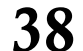

Daerah untuk mendanai pelaksanaan otonomi daerah sesuai dengan potensi daerah sebagai perwujudan desentralisasi. Kesejahteraan masyarakat akan banyak tergantung pada pemerintah daerah dengan adanya otonomi daerah ini, sehingga pemerintah daerah harus menggali semaksimal mungkin sumber-sumber Pendapatan Asli Daerahnya, dikarenakan PAD menjadi salah satu indikator dalam pengukur keberhasilan dari penyelenggaraan otonomi daerah. Semakin tinggi PAD maka semakin tinggi pula kemampuan pemerintah daerah untuk membiayai kebutuhannya sendiri. Hal ini membuktikan bahwa pemerintah daerah telah berhasil menyelenggarakan otonomi daerah. Demikian sebaliknya, jika PAD yang didapat pemerintah daerah semakin sedikit atau mengalami penurunan, maka penyelenggaraan otonomi daerah belum maksimal (Zainuddin, 2016).

Kota Bogor menjadi salah satu daerah otonom yang diberikan kewenangan dalam melaksanakan otonomi daerah. Kota Bogor memiliki letak yang sangat strategis, karena berjarak $60 \mathrm{~km}$ dari Jakarta Ibu Kota Negara Republik Indonesia, serta 120 km dari Bandung sebagai Ibu Kota Provinsi Jawa Barat. Kota Bogor sering dijuluki sebagai kota hujan karena curah hujan disini sangat tinggi sekitar $3000 \mathrm{~s} / \mathrm{d} 4000 \mathrm{~mm}$ per tahun (Novi, 2017). Adapun realiasasi Pendapatan Asli Daerah (PAD) di Kota Bogor menurut Bogor Dalam Angka 2017 untuk 3 tahun yakni dari tahun 2014 sampai tahun 2016 selalu mengalami peningkatan. Kenaikan PAD tahun 2016 terhadap 2015 mencapai 8,61\%. Kontribusi terbesar Pendapatan Asli Daerah (PAD) Kota Bogor tahun 2016, disumbangkan oleh jenis pajak di sektor kepariwisataan dan jasa. Ketiganya adalah berasal dari pajak restoran, pajak hotel, dan pajak hiburan (Resista, 2017).

Melihat pentingnya pajak bagi suatu daerah, terutama dalam menyokong pembangunan daerah itu sendiri merupakan pemasukan dana yang sangat potensial karena besarnya penerimaan pajak akan meningkat seiring laju pertumbuhan penduduk, perekonomian dan stabilitas politik. Dalam pembangunan suatu daerah, pajak memegang peranan penting dalam suatu pembangunan, termasuk pajak hotel, pajak restoran, dan pajak hiburan. Kota Bogor mempunyai potensi untuk mengembangkan pajak daerah dari sektor pariwisata. Potensi-potensi itu antara lain, Pendapatan Asli Daerah (PAD) sektor pajak dari jenis pajak hotel, pajak restoran dan pajak hiburan terus meningkat setiap tahunnya. Berdasarkan data Badan Pendapatan Daerah tahun 20102015 terlihat peningkatan dari masing-masing pajak daerah tersebut (data.kotabogor.go.id).

Potensi yang dimiliki lainnya adalah jumlah wisatawan yang berkunjung ke Kota Bogor yang terus meningkat setiap tahunnya. Hal ini sejalan dengan pertumbuhan dan perkembangan Kota Bogor yang semakin pesat. Berdasarkan data Kota Bogor Dalam Angka 2018, pada tahun 2016 di Kota Bogor wisatawan yang berkunjung sebanyak 5.262.224 orang, terdiri dari 5.017.578 wisatawan domestik dan 244.646 wisatawan mancanegara. Kota Bogor merupakan salah satu kota tujuan wisata dan kota tujuan kegiatan seminar lokakarya dan kegiatan lainnya yang bersifat nasional dan internasional. Hal ini berhubungan sangat erat antara pertumbuhan jumlah wisatawan yang datang ke Kota Bogor dengan peningkatan jumlah Pendapatan Asli Daerah (PAD) Kota Bogor dari sektor pajak hotel, pajak restoran, dan pajak hiburan. Untuk mengoptimalkan pemungutan pajak hotel, pajak restoran dan pajak hiburan maka perlu dilakukan perhitungan penerimaan pajak daerah yang akurat sehingga diketahui tingkat efektivitas, laju pertumbuhan, dan bagaimana kontribusinya terhadap Pendapatan Asli Daerah (PAD). Penelitian ini fokus pada pembahasan 3 jenis pajak yang memiliki potensi dari sektor pariwisata, yaitu pajak hotel, pajak restoran, dan pajak hiburan.

\section{TINJAUAN PUSTAKA \\ Pendapatan Asli Daerah}

Pengertian Pendapatan Asli Daerah (PAD) adalah "Pendapatan Asli Daerah (PAD) yaitu pendapatan yang diperoleh daerah dan dipungut berdasarkan peraturan daerah sesuai dengan peraturan perundang-undangan" (Sihaaan,2015:15). PAD bertujuan 
memberikan kewenangan kepada Pemerintah Daerah untuk mendanai pelaksanaan otonomi daerah sesuai dengan potensi Daerah perwujudan Desentralisasi (UndangUndang Nomor 33 Tahun 2004). Dalam Undang-Undang Nomor 33 Tahun 2004, Pendapatan Asli Daerah (PAD) terdiri dari, pajak daerah, retribusi daerah, hasil pengelolaan kekayaan daerah yang dipisahkan, dan Lain-lain PAD yang sah (meliputi hasil penjualan kekayaan daerah yang tidak dipisahkan; jasa giro; pendapatan bunga; keuntungan selisih nilai tukar rupiah terhadap mata uang asing; dan komisi, potongan ataupun bentuk lain sebagai akibat dari penjualan dan/atau pengadaan barang dan/atau jasa oleh daerah).

Pajak

Rochmat Soemitro: "Pajak adalah Iuran rakyat kepada kas negara berdasarkan undang-undang (yang dapat dipaksakan) dengan tidak mendapat jasa timbal balik (kontraprestasi) yang langsung dapat ditunjukkan dan yang digunakan untuk membayar pengeluaran umum." (Resmi, 2012:1). Menurut S.I. Djajadinigrat: "Pajak sebagai suatu kewajiban menyerahkan sebagian dari kekayaan ke kas negara yang disebabkan suatu keadaan, kejadian, dan perbuatan yang memberikan kedudukan tertentu, tetapi bukan sebagai hukuman, menurut peraturan yang ditetapkan pemerintah serta dapat dipaksakan, tetapi tidak ada jasa timba balik dari negara secara langsung, untuk memelihara kesejahteraan secara umum."(Resmi, 2012:1).

\section{Pajak Daerah}

Undang-Undang Nomor 28 Tahun 2009 tentang Pajak Daerah dan Retribusi Daerah mendefinisikan pajak daerah sebagai berikut: Pajak Daerah, yang selanjutnya disebut Pajak, adalah kontribusi wajib kepada Daerah yang terutang oleh orang pribadi atau badan yang bersifat memaksa berdasarkan Undang-Undang, dengan tidak mendapatkan imbalan secara langsung dan digunakan untuk keperluan daerah bagi sebesar-besarnya kemakmuran rakyat.

Sesuai dengan pembagian administrasi daerah, Menurut Undang-Undang Nomor 28 Tahun 2009 Pajak Daerah dapat digolongkan menjadi dua macam yaitu (1) Pajak Daerah Tingkat I atau Pajak Provinsi, terdiri atas: Pajak Kendaraan Bermotor, Bea Balik Nama Kendaraan Bermotor, Pajak Bahan Bakar Kendaraan Bermotor, Pajak Air Permukaan, Pajak Rokok. (2) Pajak Daerah Tingkat II atau Pajak Kabupaten/Kota, terdiri atas: Pajak Hotel, Pajak Restoran, Pajak Hiburan, Pajak Reklame, Pajak Penerangan Jalan, Pajak Mineral Bukan Logam dan Batuan, Pajak Parkir, Pajak Air Tanah, Pajak Sarang Burung Walet, Pajak Bumi dan Bangunan Perdesaan dan Perkotaan serta Bea Perolehan Hak atas Tanah dan Bangunan.

\section{Pajak Hotel}

Berdasarkan Peraturan Daerah Kota Bogor Nomor 12 Tahun 2011 Bab 1 Ketentuan Umum bahwa Pajak Hotel yang selanjutnya disebut pajak adalah pelayanan yang disediakan oleh hotel. Objek pajak adalah pelayanan yang disediakan oleh hotel dengan pembayaran termasuk jasa penunjang seperti: (Peraturan Daerah Kota Bogor Nomor 12 Tahun 2011) seperti: a) Fasilitas telepon, faksimili, teleks, internet, foto kopi, pelayanan cuci, setrika, transportasi, b) Fasilitas olah raga dan hiburan, antara lain pusat kebugaran (fitness center), kolam renang, spa, tenis, karaoke, pub yang disediakan atau dikelola hotel c) Jasa persewaan ruangan dan makan minum untuk kegiatan acara atau pertemuan di hotel d) Fasilitas sejenis lainnya yang disediakan atau dikelola hotel) sebagai kelengkapan hotel yang sifatnya memberikan kemudahan dan kenyamanan, e) Fasilitas olahraga dan hiburan.

Menurut Peraturan Daerah kota Bogor Nomor 12 Tahun 2011 pasal 4 ayat 1 dan 2 menjelaskan bahwa subjek pajak adalah orang pribadi atau badan yang melakukan pembayaran kepada orang pribadi atau badan yang mengusahakan hotel. Sedangkan Wajib Pajak adalah orang pribadi atau badan yang mengusahakan hotel. Berdasarkan pemungutannya, dasar pengenaan pajak hotel ditetapkan sesuai dengan peraturan daerahnya masing-masing. Berdasarkan Peraturan Daerah Kota Bogor Nomor 12 Tahun 2011 Pasal 5 dan 6 tentang Pajak Hotel, dasar pengenaan pajak adalah jumlah pembayaran atau yang seharusnya dibayar kepada hotel. Tarif pajak ditetapkan sebesar
Taxes and Local

Revenue

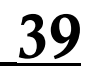


Taxes and Local Revenue

$10 \%$. Sedangkan perhitungan pajak menurut pasal 7 besaran pokok pajak yang terutang dihitung dengan cara mengalikan tarif pajak 10\% dengan dasar pengenaan pajak.

\section{Pajak Restoran}

Menurut Peraturan Daerah Kota Bogor Nomor 6 Tahun 2011 pajak restoran yang selanjutnya disebut pajak adalah pajak atas pelayanan restoran. Objek Pajak dalam Peraturan Daerah Kota Bogor Nomor 6 Tahun 2011 adalah pelayanan yang disediakan oleh restoran. Pelayanan yang disediakan restoran yang dimaksud meliputi pelayanan penjualan makanan dan/minuman yang dikonsumsi oleh pembeli, baik dikonsumsi di tempat pelayanan maupun di tempat lain. Berdasarkan Peraturan Daerah Kota Bogor Nomor 6 Tahun 2011 bahwa subjek pajak adalah orang pribadi atau badan yang membeli makanan dan/minuman dari restoran. Sedangkan Wajib Pajak adalah orang pribadi atau badan yang mengusahakan restoran.

Berdasarkan Peraturan Daerah Kota Bogor Nomor 6 Tahun 2011 dasar pengenaan pajak adalah jumlah pembayaran yang diterima atau yang seharusnya diterima restoran. Tarif pajak ditetapkan sebesar $10 \%$ (sepuluh persen). Besaran pokok pajak yang terutang dihitung dengan cara mengalikan tarif pajak 10\% dengan dasar pengenaan pajak.

\section{Pajak Hiburan}

Pajak Hiburan menurut Peraturan Daerah Kota Bogor Nomor 3 Tahun 2007 Bab I Ketentuan Umum bahwa Pajak Hiburan yang selanjutnya disebut pajak adalah pungutan daerah atas setiap penyelenggaraan hiburan. Berdasarkan Peraturan Daerah Kota Bogor Nomor 3 Tahun 2007 obyek pajak adalah penyelenggaraan hiburan dengan dipungut bayaran antara lain: Pertunjukan film; Pertunjukan pagelaran kesenian, musik, tari dan sejenisnya; Karaoke; Permainan Billiar; Permainan ketangkasan manual, mekanik, elektronik dan sejenisnya; Panti pijat/refleksi, mandi uap, SPA (aroma terapi); Pertunjukan atau Pertandingan olah raga dan sejenisnya.

Berdasarkan Peraturan Daerah Kota Bogor Nomor 3 Tahun 2007 subyek pajak adalah orang pribadi atau badan yang menonton dan/atau menikmati hiburan. Sedangkan Wajib Pajak adalah orang pribadi atau badan yang menyelenggarakan hiburan. Menurut Peraturan Daerah Kota Bogor Nomor 3 Tahun 2007 Dasar pengenaan pajak adalah jumlah pembayaran atau yang seharusnya dibayar untuk menonton dan/atau menikmati hiburan. Sedangkan tarif pajak hiburan terdiri dari:

a. Tarif pajak untuk pertunjukan film di bioskop ditetapkan sebagai berikut :

HTM di atas Rp. 35.000,00 sebesar 15\% (lima belas persen);

HTM Rp. 10.000,00 s.d Rp. 35.000,00 sebesar 10\% (sepuluh persen);

HTM dibawah Rp. 10.000,00 sebesar 5\% (lima persen).

b. Tarif pajak untuk penyelenggaraan hiburan selain yang disebutkan diatas ditetapkan sebagai berikut :

1. Untuk pertunjukan pagelaran kesenian, musik, tari dan sejenisnya antara lain pagelaran musik dan/atau tari, pertunjukan sirkus, pameran seni, pameran busana, atau kontes kecantikan yang pembayarannya dibayarkan satu persatu atau kesatuan ditetapkan sebesar $10 \%$ (sepuluh persen) dari pembayaran;

2. Untuk penyelenggaraan karaoke, panti pijat/Refleksi, mandi uap, SPA (aroma terapi) atau sejenisnya ditetapkan sebesar 25\% (dua puluh lima persen) dari pembayaran;

3. Untuk billiar ditetapkan sebesar $10 \%$ (sepuluh persen) dari pembayaran;

4. Untuk penyelenggaraan pertunjukan atau pertandingan olah raga dan sejenisnya ditetapkan sebesar $10 \%$ (sepuluh persen) dari pembayaran;

5. Untuk penyelenggaraan dan permainan ketangkasan manual, mekanik, elektronik dan sejenisnya ditetapkan sebesar $20 \%$ (dua puluh persen) dari pembayaran;

c. Penyelenggaraan hiburan dengan pembayaran tanpa menggunakan HTM dikenai pajak dengan tarif sesuai dengan jenis hiburan sebagaimana dimaksud pada point 2 dan dikenakan sanksi administrasi sebesar 25\% (dua puluh lima persen) dari pembayaran. 
Mahmudi (2010:143) menyatakan bahwa efektivitas merupakan hubungan antara keluaran dengan tujuan atau sasaran yang harus dicapai. Dikatakan efektif apabila proses kegiatan mencapai tujuan dan sasaran akhir kebijakan (spending wisely). Semakin besar output yang dihasilkan terhadap pencapaian tujuan dan sasaran yang ditentukan, maka semakin efektif proses kerja suatu unit organisasi. Adapun kriteria efektivitas tersebut sebagai berikut.

Tabel 1 Interpretasi Nilai Efektivitas

\begin{tabular}{cc}
\hline Persentase & Kriteria \\
\hline$>100 \%$ & Sangat Efektif \\
$90-100 \%$ & Efektif \\
$80-90 \%$ & Cukup Efektif \\
$60-80 \%$ & Kurang Efektif \\
$<60 \%$ & Tidak Efektif \\
\hline
\end{tabular}

Sumber : Kemendragi No. 690.900.327 (Mahmudi, 2010:143)

Mahmudi (2010:143) dalam (Alfan dkk, 2015) menyatakan bahwa efektivitas merupakan hubungan antara keluaran dengan tujuan atau sasaran yang harus dicapai. Untuk menganalisis tingkat efektifitas dari pajak hotel, pajak restoran, dan pajak hiburan maka peneliti menggunakan rumus :

\section{Laju Pertumbuhan Pajak Daerah}

$$
\text { Efektifitas }=\frac{\text { Realisasi Penerimaan Pajak }}{\text { Target Penerimaan Pajak }} \times 100 \%
$$

Laju pertumbuhan ekonomi merupakan proses kenaikan output per kapita dalam jangka panjang dan apabila diterapkan dalam pajak daerah, laju pertumbuhan ini adalah proses kenaikan penerimaan pajak dalam jangka panjang. Laju pertumbuhan ini menunjukkan kemampuan daerah dalam mempertahankan dan meningkatkan keberhasilan daerah yang telah dicapainya dari periode ke periode berikutnya (Halim, 2004). Untuk menghitung laju pertumbuhan pajak digunakan rumus sebagai berikut (Halim, 2004:163) :

Keterangan :

$$
G_{\%}=\frac{X_{t}-X_{(t-1)}}{X_{(t-1)}} \times 100 \%
$$

$G_{\%} \quad:$ Pertumbuhan pajak daerah per tahun

$X_{t} \quad$ : Realisasi penerimaan pajak daerah tahun tertentu

$X_{(t-1)}$ : Realisasi penerimaan pajak daerah pada tahun sebelumnya

\section{Kontribusi Pajak Daerah}

Kontribusi adalah sesuatu yang diberikan bersama-sama dengan pihak lain untuk tujuan biaya, atau kerugian tertentu dan bersama-sama (Guritno, 67:1999). Kriteria yang digunakan dalam menilai kontribusi pajak daerah terhadap PAD sebagai berikut.

Tabel 2. Klasifikasi Kriteria Nilai Kontribusi Pajak Daerah

\begin{tabular}{cc}
\hline Persentase & Kriteria \\
\hline $0,00 \%-10 \%$ & Sangat Kurang \\
$10,10 \%-20 \%$ & Kurang \\
$20,10 \%-30 \%$ & Sedang \\
$30,10 \%-40 \%$ & Cukup Baik \\
$40,10 \%-50 \%$ & Baik \\
Diatas $50 \%$ & Sangat Baik \\
\hline
\end{tabular}

Sumber: Kemendragi No. 690.900.327 (Hasannudin, 2015)

Dalam mengetahui kontribusi dilakukan dengan membandingkan penerimaan pajak daerah (khususnya pajak hotel, pajak restoran dan pajak hiburan) periode tertentu dengan penerimaan PAD periode tertentu pula. Untuk mengetahui besar kontribusi pajak hotel, pajak restoran, dan pajak hiburan terhadap Pendapatan Asli Daerah Kota Bogor, digunakan rumus: (Alfan dkk, 2015).

$$
\text { Kontribusi }=\frac{\text { Realisasi } \text { Penerimaan Pajak }}{\text { Realisasi Penerimaan } P A D} \times 100 \%
$$


Taxes and Local

Revenue

$\underline{42}$

\section{METODE PENELITIAN}

Penelitian ini dilaksanakan pada Badan Pendapatan Daerah Kota Bogor yang beralamat di Jalan Pemuda No. 31, Tanah Sareal, Kota Bogor 16162. Lokasi ini dipilih karena merupakan sumber data maupun informasi yang dibutuhkan. Penelitian ini dilakukan pada bulan 15 Februari 2019 sampai dengan 15 Mei 2019. Metode analisis data yang digunakan dalam penelitian ini adalah menggunakan metode analisis deskriptif kualitatif, analisis deskriptif kualitatif adalah analisis yang diwujudkan dengan cara menggambarkan kenyataan atau keadaan-keadaan atas suatu objek dalam bentuk uraian kalimat berdasarkan keterangan-keterangan dari pihak-pihak yang berhubungan langsung dengan penelitian ini (Tarigan, 2013)

\section{HASIL DAN PEMBAHASAN}

Analisis Tingkat Efektivitas Pemungutan Pajak Hotel

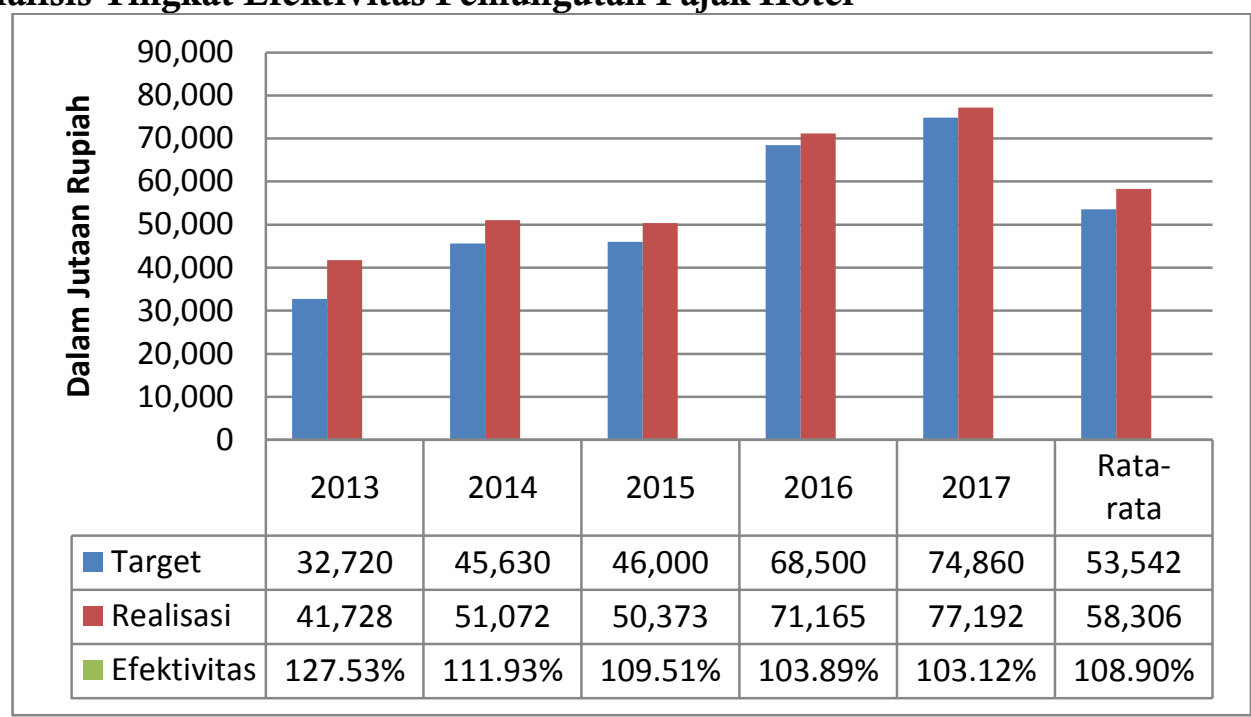

Gambar 1 Efektivitas Pajak Hotel Kota Bogor Tahun 2013-2017

Berdasarkan Gambar 1 bahwa target pajak hotel yang ditetapkan oleh Badan Pendapatan Daerah di Kota Bogor pada tahun 2013-2017 selalu mengalami kenaikan di setiap tahunnya. Realisasi penerimaan pajak hotel dari tahun 2013 sampai dengan tahun 2017 selalu melebihi dari target yang telah ditetapkan sehingga rasio efektivitasnya dari tahun ketahun mencapai persentase melebihi $100 \%$ hal ini menandakan bahwa kinerja dari Badan Pendapatan Daerah dalam memungut pajak daerah khususnya untuk pajak hotel di Kota Bogor dapat dikatakan sangat efektif.

\section{Analisis Tingkat Efektivitas Pemungutan Pajak Restoran}

Berdasarkan Gambar 2 diketahui bahwa realisasi penerimaan pajak restoran di Kota Bogor dari tahun 2013-2017 selalu melebihi dari target yang telah ditetapkan oleh Badan Pendapatan Daerah dan dalam pencapaian rasio efektivitasnya telah mencapai lebih dari 100 persen hal ini menandakan bahwa pemungutan pajak restoran di Kota Bogor sudah sangat efektif. Adanya peningkatan wajib pajak restoran dapat meningkatkan penerimaan atau realisasi dari pajak restoran tersebut sehingga target yang ditetapkan pun ditingkatkan dari tahun ke tahunnya. Bapenda selalu melakukan upaya untuk memenuhi target yang telah ditetapkan dengan cara intensifikasi dan ekstensifikasi pajak. Intensifikasi pajak merupakan upaya yang dilakukan dalam mengoptimalkan wajib pajak yang sudah ada. Sedangkan ekstensifikasi adalah upaya yang dilakukan dengan mencari wajib pajak yang baru. Sehingga dengan upaya yang dilakukan tersebut dapat meningkatkan PAD Kota Bogor yang bersumber dari pajak daerah khususnya yaitu pajak restoran. 


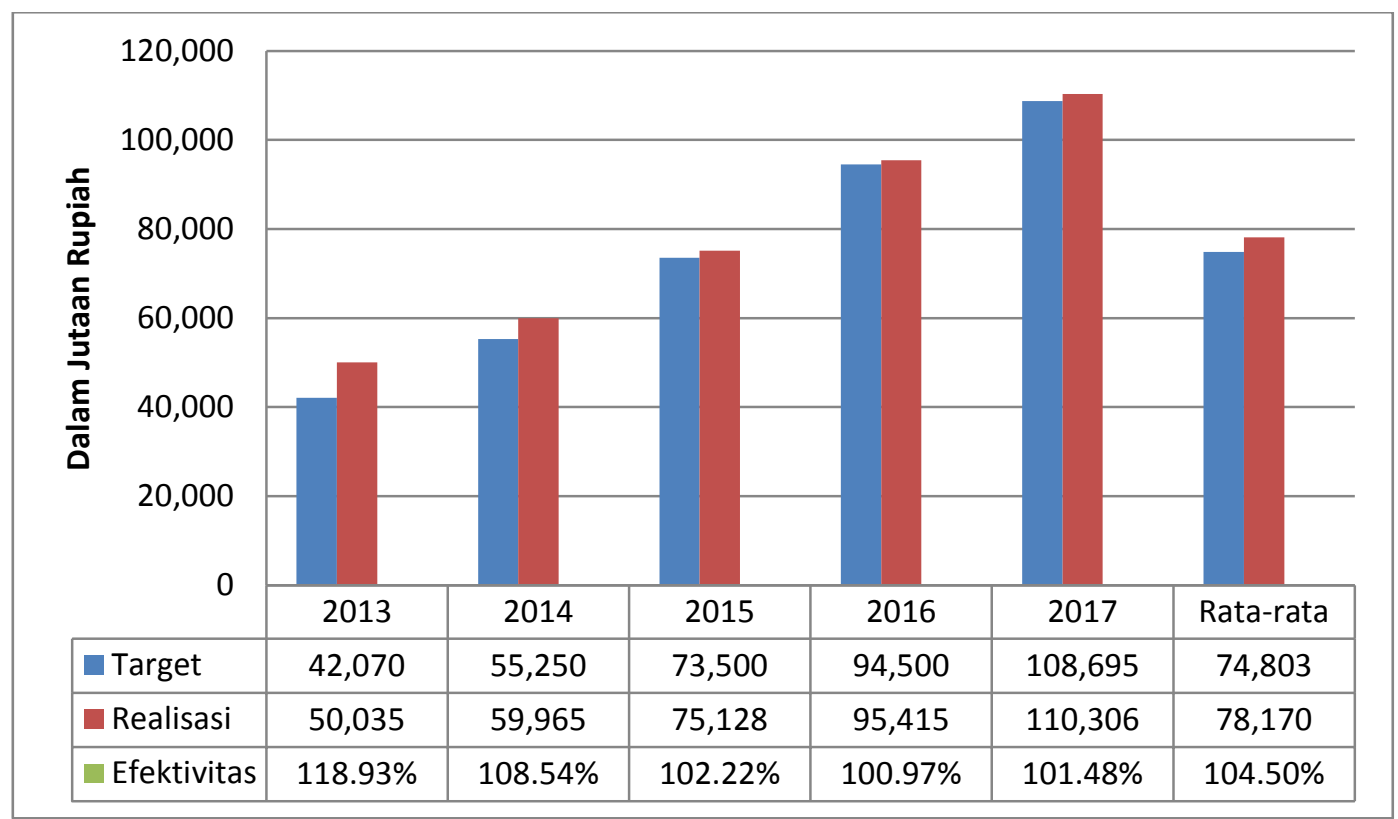

Taxes and Local Revenue

Gambar 2 Efektivitas Pajak Restoran Kota Bogor Tahun 2013-2017

\section{Analisis Tingkat Efektivitas Pemungutan Pajak Hiburan}

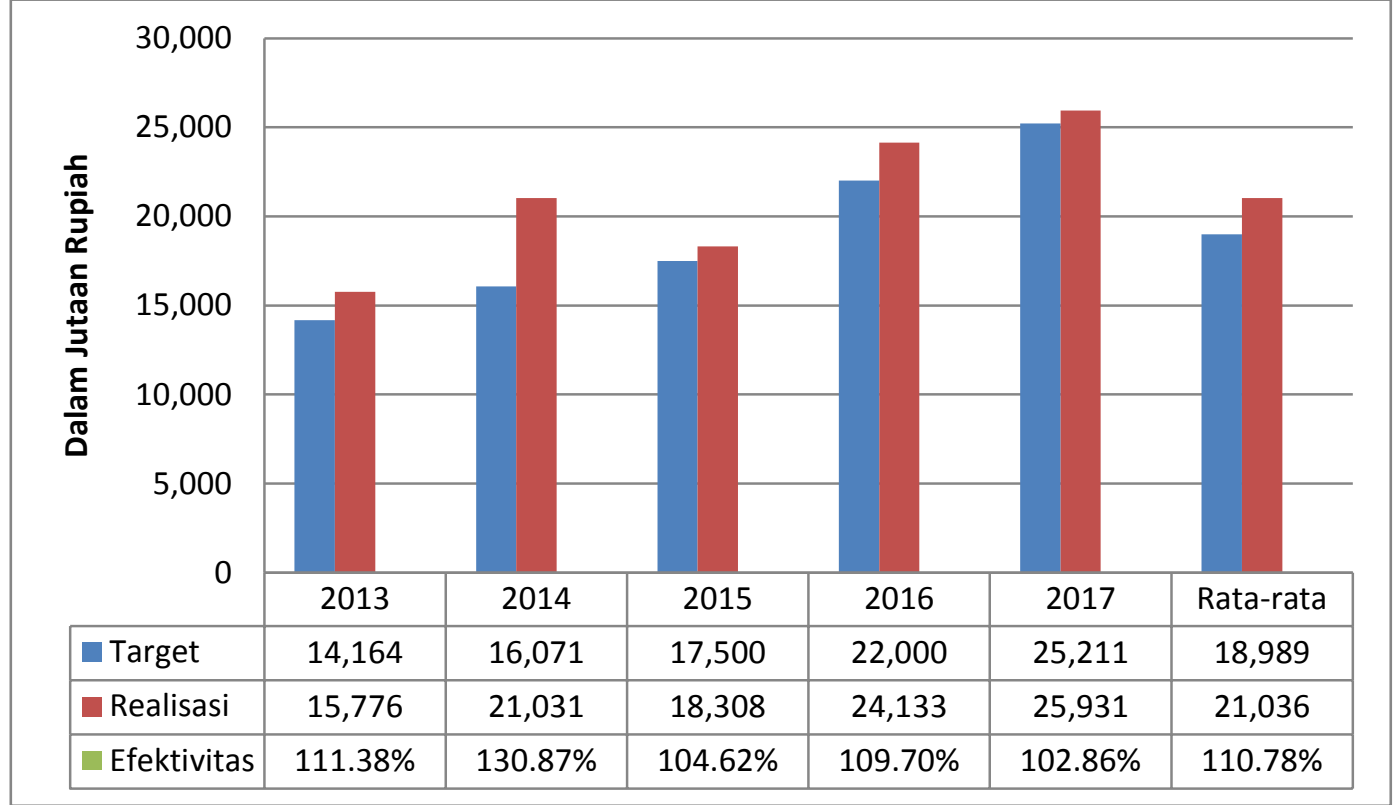

Gambar 3 Efektivitas Pajak Hiburan Kota Bogor Tahun 2013-2017

Gambar 3 menunjukkan bahwa target yang ditetapkan oleh Badan Pendapatan Daerah Kota Bogor selalu mengalami kenaikan disetiap tahunnya. Adanya penerimaan realisasi yang meningkat ini dikarenakan peningkatan jumlah wajib pajak hiburan dari tahun 2013 sampai dengan tahun 2017. Kinerja Bapenda juga dalam hal memungut pajak hiburan dapat dikatakan sudah baik hal ini ditandai dengan realisasi penerimaan pajak hiburan di Kota Bogor dari tahun ke tahunnya yang selalu melampaui target yang telah ditetapkan dan perolehan persentase rasio efektivitas yang melebihi 100 persen dapat dikatakan sangat efektif.

\section{Analisis Laju Pertumbuhan Pajak Hotel}

Pertumbuhan pajak hotel di Kota Bogor meningkat seiring meningkatnya jumlah wisatawan domestik maupun wisatawan yang berasal dari luar negeri. Pada tahun 2015 realisasi dari pajak hotel mengalami penurunan dari tahun sebelumnya hal ini disebabkan karena pengaruh adanya surat edaran Menteri Pendayagunaan Aparatur Negara dan Reformasi Birokrasi mengenai kebijakan untuk melarang PNS dan Instansi 
Taxes and Local Revenue

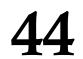

pemerintah daerah untuk mengadakan seminar/rapat/workshop/pelatihan di hotel, hal ini memberikan dampak pada hotel yang ada di Kota Bogor dimana penerimaan pendapatan pemilik hotel menjadi berkurang karena tidak adanya pemasukan dari penyewaan gedung atau ruangan untuk seminar/rapat/workshop/pelatihan di semua hotel yang berada di Kota Bogor. Selain itu dikarenakan 60\% industri perhotelan di Kota Bogor mengusung konsep MICE (Meeting, Incentive, Convension and Exhibition) yakni pertemuan, insentif, konvensi dan pameran sehingga hotel dengan konsep MICE ini sangat bergantung pada kegiatan rapat kementerian daerah serta BUMN. Selain itu begitu pesatnya pertumbuhan hotel dari tahun 2014-2015 dengan lahan yang terbatas di Kota Bogor menjadikan pemerintah Kota Bogor memutuskan langkah untuk mengerem pertumbuhan hotel, diantaranya dengan mengeluarkan moratorium atau penghentian sementara izin pembangunan hotel sejak tahun 2015 kecuali untuk proyek-proyek yang sudah berjalan. Pembangunan hotel yang ada sampai dengan saat ini merupakan izin pembangunan hotel terdahulu dan baru terealisasikan proses pembangunannya. Hasil moratorium tersebut berdampak pada laju pertumbuhan WP pada tahun 2016 dan 2017 yang mengalami pertumbuhan hanya sebesar 7,03\% dan 9,09\%. Hal ini menjadikan upaya Bapenda dalam memenuhi penerimaan realisasi pajak hotel dengan mengoptimalkan wajib pajak yang sudah ada/ terdaftar atau intensifikasi pajak. Tabel 3 Laju Pertumbuhan Pajak Hotel Kota Bogor Tahun 2013-2017

\begin{tabular}{ccccc}
\hline \multirow{2}{*}{ Tahun } & $\begin{array}{c}\text { Jumlah } \\
\text { WP }\end{array}$ & $\begin{array}{c}\text { Realisasi Pajak } \\
\text { Hotel (Rp) }\end{array}$ & $\begin{array}{c}\text { Laju Pertumbuhan } \\
\text { Pajak }\end{array}$ & $\begin{array}{c}\text { Laju Pertumbuhan } \\
\text { WP }\end{array}$ \\
\hline 2013 & 90 & 41.728 .119 .975 & - & - \\
2014 & 103 & 51.072 .782 .235 & $22,39 \%$ & $14,44 \%$ \\
2015 & 185 & 50.373 .226 .573 & $-1,37 \%$ & $79,61 \%$ \\
2016 & 198 & 71.165 .895 .875 & $41,28 \%$ & $7,03 \%$ \\
2017 & 216 & 77.192 .419 .056 & $8,47 \%$ & $9,09 \%$ \\
\multicolumn{2}{c}{ Rata-rata } & $14,15 \%$ & $22,03 \%$ \\
\hline
\end{tabular}

Analisis Laju Pertumbuhan Pajak Restoran

Tabel 4 Laju Pertumbuhan Pajak Restoran Kota Bogor Tahun 2013-2017

\begin{tabular}{ccccc}
\hline \multirow{2}{*}{ Tahun } & $\begin{array}{c}\text { Jumlah } \\
\text { WP }\end{array}$ & $\begin{array}{c}\text { Realisasi Pajak } \\
\text { Restoran (Rp) }\end{array}$ & $\begin{array}{c}\text { Laju Pertumbuhan } \\
\text { Pajak }\end{array}$ & $\begin{array}{c}\text { Laju Pertumbuhan } \\
\text { WP }\end{array}$ \\
\hline 2013 & 351 & 50.035 .057 .749 & - & - \\
2014 & 451 & 59.965 .768 .360 & $19,85 \%$ & $28,49 \%$ \\
2015 & 548 & 75.128 .975 .542 & $25,29 \%$ & $21,51 \%$ \\
2016 & 692 & 95.415 .220 .190 & $27,00 \%$ & $26,28 \%$ \\
2017 & 826 & 110.306 .908 .127 & $15,61 \%$ & $19,36 \%$ \\
\multicolumn{2}{c}{ Rata-rata } & $17,55 \%$ & $19,13 \%$ \\
\hline
\end{tabular}

Sumber: Data Diolah

Laju pertumbuhan pajak restoran yang positif ini dikarenakan jumlah restoran di Kota Bogor yang semakin meningkat sehingga dapat meningkatkan realisasi penerimaan dari pajak restoran. Namun pada tahun 2017 adanya penurunan persentase pertumbuhan pajak ini disebabkan karena pada kenaikan realisasi penerimaan tahun ini dibandingkan dengan tahun sebelumnya, adanya kenaikan dari realisasi penerimaan pajak restoran tersebut tidak signifikan. Hal ini disebabkan adanya peningkatan jumlah wajib pajak baru/ restoran baru yang terdaftar tidak diimbangi dengan banyaknya jumlah pengunjung sehingga terjadi penutupan restoran lama diakibatkan bangkrut, habis masa kontrak atau sudah tidak melakukan kegiatan usaha tersebut sehingga adanya penutupan wajib pajak/ restoran. Selain itu kebanyakan dari pengunjung restoran baru hanya sekedar coba-coba dan sebagian besar tidak menjadi pelanggan tetap akibatnya mempengaruhi persentase pertumbuhan pajak restoran. 

dengan tahun 2017 secara persentase mengalami fluktuasi. Namun pada tahun 2015 laju pertumbuhan pajak hiburan mengalami penurunan persentase sebesar minus $12,95 \%$ dengan pertumbuhan WP sebesar $8,14 \%$ hal ini disebabkan adanya pembatasan jam operasional hanya sampai pada pukul 24.00 WIB pada Tempat Hiburan Malam (THM) di Kota Bogor dan juga beberapa THM yang menyalahgunakan pelaporan pajaknya yang mengakibatkan adanya penurunan penerimaan pendapatan pajak hiburan. Sedangkan pada tahun 2017 penurunan laju pertumbuhan pajak yang tidak diimbangi dengan pertumbuhan WP disebabkan penurunan acara hiburan atau acara yang diselenggarakan dan jumlah pengunjung hiburan tersebut. Adanya tempat-tempat hiburan baru serta adanya penutupan untuk tempat-tempat hiburan yang lama.

Tabel 5 Laju Pertumbuhan Pajak Hiburan Kota Bogor Tahun 2013-2017

\begin{tabular}{ccccc}
\hline Tahun & $\begin{array}{c}\text { Jumlah } \\
\text { WP }\end{array}$ & $\begin{array}{c}\text { Realisasi Pajak } \\
\text { Hiburan (Rp) }\end{array}$ & $\begin{array}{c}\text { Laju Pertumbuhan } \\
\text { Pajak }\end{array}$ & $\begin{array}{c}\text { Laju Pertumbuhan } \\
\text { WP }\end{array}$ \\
\hline 2013 & 69 & 15.776 .049 .233 & - & - \\
2014 & 86 & 21.031 .414 .292 & $33,31 \%$ & $24,64 \%$ \\
2015 & 93 & 18.308 .544 .830 & $-12,95 \%$ & $8,14 \%$ \\
2016 & 104 & 24.133 .785 .705 & $31,82 \%$ & $11,83 \%$ \\
2017 & 118 & 25.931 .011 .958 & $7,45 \%$ & $13,46 \%$ \\
\multicolumn{6}{c}{ Rata-rata } & $11,93 \%$ & $11,61 \%$ \\
\hline
\end{tabular}

Sumber: Data Diolah

\section{Analisis Kontribusi Pajak Hotel Terhadap PAD}

Berdasarkan ketentuan Kemendagri No. 690.900.327 tahun 1996 bahwa kriteria kontribusi pajak hotel terhadap PAD di Kota Bogor sangat kurang, dimana besarnya persentase diantara $0,00 \%-10,00 \%$. Terjadinya fluktuasi kontribusi dari pajak hotel terhadap PAD di Kota Bogor dipengaruhi karena adanya kenaikan atau penurunan jumlah pengunjung yang menginap di hotel, sehingga mempengaruhi penerimaan pajak hotel yang berpengaruh terhadap kontribusi pajak hotel tersebut terhadap PAD di Kota Bogor. Adanya penurunan persentase kontribusi pajak hotel terhadap PAD pada tahun 2015 disebabkan adanya penurunan realisasi pajak hotel dari tahun sebelumnya. Hal ini dikarenakan adanya kebijakan dari pemerintah pusat melalui Menteri Pendayagunaan Aparatur Negara dan Reformasi Birokrasi mengenai larangan pejabat di pemerintahan untuk mengadakan rapat di hotel-hotel. Sedangkan pada tahun 2017 walaupun realisasi dari penerimaan pajak hotel meningkat secara nominal namun adanya penurunan secara persentase dari kontribusi pajak hotel terhadap PAD. Hal ini dikarenakan adanya peningkatan realisasi pajak dari sektor pajak lainnya yaitu Bea Perolehan Hak atas Tanah dan Bangunan (BPHTB) yang mempengaruhi kontribusi pajak hotel.

Tabel 6 Kontribusi Pajak Hotel di Kota Bogor Tahun 2013-2017

\begin{tabular}{cccccc}
\hline No & Tahun & $\begin{array}{c}\text { Realisasi Pajak } \\
\text { Hotel (Rp) }\end{array}$ & $\begin{array}{c}\text { Realisasi PAD } \\
(\mathrm{Rp})\end{array}$ & Kontribusi & Kriteria \\
\hline 1 & 2013 & 41.728 .119 .975 & 464.695 .880 .485 & $8,98 \%$ & Sangat Kurang \\
2 & 2014 & 51.072 .782 .235 & 544.835 .708 .254 & $9,37 \%$ & Sangat Kurang \\
3 & 2015 & 50.373 .226 .573 & 627.594 .065 .141 & $8,03 \%$ & Sangat Kurang \\
4 & 2016 & 71.165 .895 .875 & 783.873 .587 .219 & $9,08 \%$ & Sangat Kurang \\
5 & 2017 & 77.192 .419 .056 & 978.197 .741 .947 & $7,89 \%$ & Sangat Kurang \\
\multicolumn{2}{l}{ Rata-Rata } & 58.306 .488 .743 & 679.839 .396 .609 & $8,58 \%$ & Sangat Kurang \\
\hline
\end{tabular}

Sumber : Data Diolah

Analisis Kontribusi Pajak Restoran Terhadap PAD

Berdasarkan ketentuan Kemendagri No.690.900.327 kriteria kontribusi pajak restoran di Kota Bogor termasuk kategori kurang dimana besarnya persentase diantara $10,10 \%$ sampai $20,00 \%$ meskipun demikian secara persentase 2013-2016 selalu 
Taxes and Local

Revenue

$\underline{46}$

mengalami kenaikan disetiap tahunnya hal ini dikarenakan adanya peningkatan jumlah wajib pajak restoran yang terdaftar di Bapenda Kota Bogor dari tahun ke tahunnya dan pengaruh kunjungan dari pengujung restoran yang meningkat seiring dengan banyaknya restoran/rumah makan yang ada di Kota Bogor. Adanya perkembangan dunia bisnis dan salah satunya dalam bidang kuliner di Kota Bogor juga menjadikan Kota Bogor sebagai Kota Kuliner. Sementara pada tahun 2017 terjadi penurunan kontribusi restoran disebabkan adanya realisasi pajak dari sektor pajak lainnya yaitu Bea Perolehan Hak atas Tanah dan Bangunan (BPHTB) yang meningkat cukup signifikan.

Tabel 5 Kontribusi Pajak Restoran di Kota Bogor Tahun 2013-2017

\begin{tabular}{cccccc}
\hline No & Tahun & $\begin{array}{c}\text { Realisasi Pajak } \\
\text { Restoran (Rp) }\end{array}$ & Realisasi PAD (Rp) & Kontribusi & Kriteria \\
\hline 1 & 2013 & 50.035 .057 .749 & 464.695 .880 .485 & $10,77 \%$ & Kurang \\
2 & 2014 & 59.965 .768 .360 & 544.835 .708 .254 & $11,01 \%$ & Kurang \\
3 & 2015 & 75.128 .975 .542 & 627.594 .065 .141 & $11,97 \%$ & Kurang \\
4 & 2016 & 95.415 .220 .190 & 783.873 .587 .219 & $12,17 \%$ & Kurang \\
5 & 2017 & 110.306 .908 .127 & 978.197 .741 .947 & $11,28 \%$ & Kurang \\
\multicolumn{2}{l}{ Rata-rata } & 78.170 .385 .994 & 679.839 .396 .609 & $11,50 \%$ & Kurang \\
\hline
\end{tabular}

Sumber : Data Diolah

\section{a. Analisis Kontribusi Pajak Hiburan Terhadap PAD}

Berdasarkan ketentuan Kemendagri No. 690.900.327 tahun 1996 kriteria kontribusi pajak hiburan terhadap PAD di Kota Bogor sangat kurang, dimana besarnya persentase diantara $0,00 \%-10 \%$. Terjadinya fluktuasi dari kontribusi pajak hiburan terhadap Pendapatan Asli Daerah di Kota Bogor adanya kenaikan/ penurunan acara hiburan atau acara yang diselenggarakan dan jumlah pengunjung hiburan tersebut. Adanya tempat-tempat hiburan baru serta adanya penutupan tempat-tempat hiburan yang lama sehingga menyebabkan adanya peralihan jumlah pengunjung tersebut. Selain itu pada tahun 2015 adanya penurunan kontribusi pajak hiburan disebabkan adanya pembatasan jam operasional bagi Tempat Hiburan Malam (THM) di kota Bogor sehingga menyebabkan realisasi penerimaan yang diterima mengalami penurunan. Sedangkan pada tahun 2017 secara realisasi penerimaan pajak hiburan mengalami kenaikan namun secara persentase kontribusi pajak hiburan terhadap PAD di Kota Bogor mengalami penurunan hal ini dikarenakan adanya kenaikan realisasi pajak yang cukup signifikan dari sektor pajak lainnya yaitu Bea Perolehan Hak atas Tanah dan Bangunan (BPHTB). Tabel 6 Kontribusi Pajak Hiburan di Kota Bogor Tahun 2013-2017

\begin{tabular}{|c|c|c|c|c|}
\hline Tahun & $\begin{array}{c}\text { Realisasi Pajak } \\
\text { Hiburan (Rp) }\end{array}$ & Realisasi PAD (Rp) & Kontribusi & Kriteria \\
\hline 2013 & 15.776 .049 .233 & 464.695 .880 .485 & $3,39 \%$ & Sangat Kurang \\
\hline 2014 & 21.031 .414 .292 & 544.835 .708 .254 & $3,86 \%$ & Sangat Kurang \\
\hline 2015 & 18.308 .544 .830 & 627.594 .065 .141 & $2,92 \%$ & Sangat Kurang \\
\hline 2016 & 24.133 .785 .705 & 783.873 .587 .219 & $3,08 \%$ & Sangat Kurang \\
\hline 2017 & 25.931 .011 .958 & 978.197 .741 .947 & $2,65 \%$ & Sangat Kurang \\
\hline Rata-rata & 21.036 .161 .204 & 679.839 .396 .609 & $3,09 \%$ & Sangat Kurang \\
\hline
\end{tabular}

Sumber : Data Diolah

\section{PENUTUP}

Berdasarkan hasil analisis dan hasil pembahasan sebelumnya, maka diperoleh kesimpulan dari hasil penelitian mengenai Analisis Efektivitas, Laju Pertumbuhan dan Kontribusi Pajak Daerah Terhadap Pendapatan Asli Daerah Di Kota Bogor Periode 2013-2017 adalah sebagai berikut : Tingkat efektivitas Pajak Hotel, Pajak Restoran dan Pajak Hiburan di Kota Bogor selama periode 2013-2017 termasuk kriteria sangat efektif. 
Hal ini dikarenakan penerimaan pajak hotel, pajak restoran dan pajak hiburan yang telah melebihi target penerimaan pajak daerah yang ditetapkan oleh Bapenda dengan tingkat efektivitas pemungutan pajak daerah yang melebihi $100 \%$ setiap tahunnya dengan rata-rata tingkat efektivitas untuk pajak hotel sebesar 108,90\%, pajak restoran sebesar $104,50 \%$ dan pajak hiburan sebesar $110,78 \%$.

Laju pertumbuhan untuk Pajak Hotel, Pajak Restoran dan Pajak Hiburan pada tahun 2013 tidak ada hasil perolehannya karena tidak termasuk kedalam perhitungan penelitian di tahun sebelumnya yaitu 2012. Untuk pajak hotel laju pertumbuhan ratarata di Kota Bogor sebesar 14,15\% Kemudian rata-rata laju pertumbuhan pajak restoran adalah $17,55 \%$ sedangkan laju pertumbuhan pajak hiburan sebesar $11,93 \%$. Adanya kenaikan/ penurunan laju pertumbuhan dari Pajak Hotel, Pajak Restoran dan Pajak Hiburan disebabkan oleh beberapa faktor diantaranya, adanya kebijakan-kebijakan dari pemerintah pusat, pengaruh naik/turunnya jumlah pengunjung yang datang, dan tingkat wisatawan yang berkunjung ke Kota Bogor.

Kontribusi pajak hotel terhadap Pendapatan Asli Daerah di Kota Bogor sangat kurang. Persentase rata-rata kontribusi pajak hotel 2013-2017 sebesar 8,58\%. Sedangkan untuk kontribusi pajak restoran terhadap Pendapatan Asli Daerah di Kota Bogor kurang. Persentase rata-rata selama periode 2013-2017 11,50\%. Serta untuk kontribusi pajak hiburan terhadap Pendapatan Asli Daerah di Kota Bogor sangat kurang. Persentase rata-rata kontribusi pajak hiburan pada tahun 2013-2017 sebesar 3,09\%. Adanya penurunan kontribusi pajak hotel, pajak restoran dan pajak hiburan dipengaruhi oleh adanya kebijakan pemerintah pusat, jumlah pengunjung dan naiknya jumlah realisasi penerimaan pajak daerah lainnya (BPHTB) yang cukup signifikan.

\section{DAFTAR PUSTAKA}

Adi, S., Martani, D., Pamungkas, B. and Simanjuntak, R.A., 2016. Analysis of the quality of performance report of the local government on websites: Indonesian case. Cogent Business \& Management, 3(1), p.1229393.

Effendy, M., Surya, T.M. and Mubarak, M.M., 2009. Pengaruh Struktur Modal Terhadap Resiko Keuangan Perusahaan. Jurnal Ilmiah Kesatuan (JIK), 11(1).

Halim, A. 2016. Manajemen Keuangan Sektor Publik Problematika Penerimaan Pemerintah (Anggaran Pendapatan dan Belanja Negara/Daerah), Salemba Empat, Jakarta.

Iriyadi, I., 2019. Prevention of Earnings Management through Audit Committee and Audit Quality in the Award-Winning and Non-Winning Companies. Journal of Accounting Research, Organization and Economics, 2(2), pp.155-169.

Kembauw, E., Munawar, A., Purwanto, M.R., Budiasih, Y. and Utami, Y., 2020. Strategies of Financial Management Quality Control in Business.

Kota Bogor Dalam Angka 2017. Badan Pusat Statistik. 2017 [Internet] [Diakses pada tanggal 13 Juli 2018]. Tersedia pada: https://bogorkota.bps.go.id

Kota Bogor Dalam Angka 2018. Badan Pusat Statistik. 2018 [Internet] [Diakses pada tanggal 22 Agustus 2018]. Tersedia pada: https://bogorkota.bps.go.id

Lamia, A.A., Serang, D.P.E., Wokas, H.R.N., 2015. Analisis Efektivitas dan Kontribusi Pemungutan Pajak Restoran, Pajak Reklame, dan Pajak Penerangan Jalan pada Pendapatan Asli Daerah Kabupaten Minahasa Utara. Jurnal Berkala Ilmiah Efisiensi Vol. 15(5):788-799.

Liana, Novi. 2017. Optimalisasi Peningkatan Pendapatan Asli Daerah Dihubungkan Pariwisata Kota Bogor dan Kabupaten Bogor. Jurnal Living Law Vol.9(1):103-115.

Mahmudi. 2010. Analisis Laporan Keuangan Pemerintah Daerah, Sekolah Tinggi Ilmu Manajemen, Yogyakarta.

Mardiasmo. 2012. Perpajakan. Edisi Revisi, Andi, Yogyakarta.

Mulyana, M., Hidayat, L. and Puspitasari, R., 2019. Mengukur Pengetahuan Investasi Para Mahasiswa Untuk Pengembangan Galeri Investasi Perguruan Tinggi. JAS-PT (Jurnal Analisis Sistem Pendidikan Tinggi Indonesia), 3(1), pp.31-52.
Taxes and Local Revenue

47


Taxes and Local Revenue

48
Pamungkas, B. and Yusuf, E.S., 2007. Penerapan Sistem Akuntansi Pemerintahan dalam Mendukung Akuntabilitas Kinerja Instansi Pemerintah (AKIP): Penerapan pada Pusat Analisis Sosial Ekonomi dan Kebijakan Pertanian Bogor. Jurnal Ilmiah Ranggagading (JIR), 7 (1), pp.8-13.

Peraturan Daerah Kota Bogor Nomor 3 Tahun 2007 tentang Pajak Hiburan

Peraturan Daerah Kota Bogor Nomor 6 Tahun 2011 tentang Pajak Restoran

Peraturan Daerah Kota Bogor Nomor 12 Tahun 2011 tentang Pajak Hotel

Purba, J.H.V. and Magdalena, A., 2017. Pengaruh Nilai Tukar Terhadap Ekspor dan Dampaknya Terhadap Pertumbuhan Ekonomi Indonesia. DeReMa Jurnal Manajemen, 12(2), pp.285-295.

Puspita, D.T. 2016. Analisis Efektivitas Penerimaan Pajak Restoran, Pajak Hotel dan Pajak Penerangan Jalan dalam Meningkatkan Pendapatan Asli Daerah Kota Depok. Skripsi. Universitas Islam Negeri Syarif Hidayahtullah Jakarta.

Rencana Staregis. 2017. [Internet] [Diakses pada tanggal 13 Juli 2018]. Tersedia pada: http://data.kotabogor.go.id

Resmi, S. 2012. Perpajakan, Salemba Empat, Jakarta.

Tarigan, K.Wanta. 2013. Efektivitas dan kontribusi PBB terhadap penerimaan pajak Di KPP Pramata Manado. Jurnal Emba Vol. 1(3):282-291.

T, Guritnno. 1999. Kamus Besar Bahasa Indonesia dan Kamus Ekonomi, Cetakan ke 8, Jakarta.

Undang-undang Republik Indonesia Nomor 23 Tahun 2014. Tentang Pemerintah Daerah

Undang-Undang Republik Indonesia Nomor 28 Tahun 2007. Tentang Ketentuan Umum dan Tata Cara Perpajakan

Undang-Undang Republik Indonesia Nomor 28 Tahun 2009. Tentang Pajak Daerah dan Retribusi Daerah. 2009. Sekretaris Negara Republik Indonesia, Jakarta.

Undang-Undang Republik Indonesia Nomor 33 Tahun 2004. Tentang Perimbangan Keuangan Antara Pemerintah Pusat dan Pemerintahan Daerah.

Vikalina, Resista. 2017. Analisis Identifikasi Sektor Perekonomian Sebagai Sektor Basis dan Sektor Potensial di Kota Bogor. Jurnal Ilmiah Ilmu Administrasi Vol. 9(2):198208.

Zainuddin. 2016. Efektivitas, Efisiensi dan Kontribusi Pajak Daerah Terhadap Pendapatan Asli Daerah Provinsi Maluku Utara. Jurnal Ilmu Ekonomi \& Sosial Vol. 7(2):156-178. 